$$
\begin{aligned}
& =574 \\
& F_{9 q} F_{q}
\end{aligned}
$$






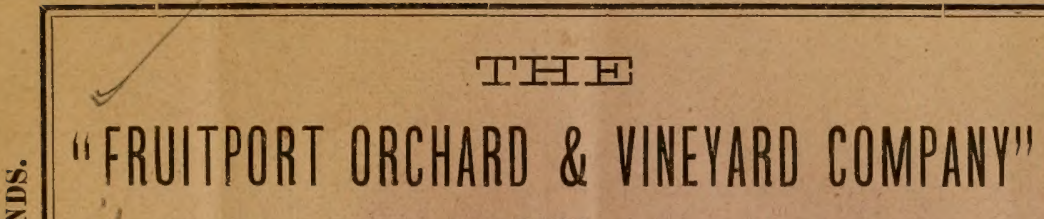 \\ HAVE \\ Sectred ahout Eighteen Square Miles of the Choicest

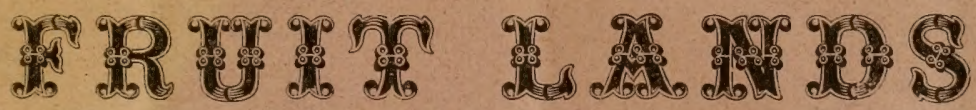 \\ IN THE CELEBRATED \\ " IIICHIGAN PEACH BELT." \\ NEAR THE TOWN OF \\ FIIIPOR I.}

Splendid Harbor, Railroads, Charming Climate, Beautiful Scenery, Pure Water, Good Society. in one of the Finest Peach Growing Regions of any Country.

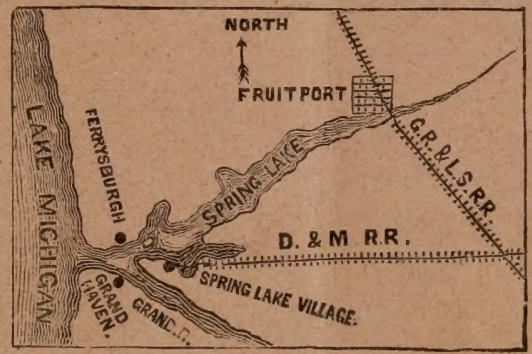

Address, E, T. GRAW, FRUTTPORT,

Via Spring Lake, MICHIGAN.

CHIOAGO :

Mathews \& Co.. Printers, 140 South Water Street.

1869 . 



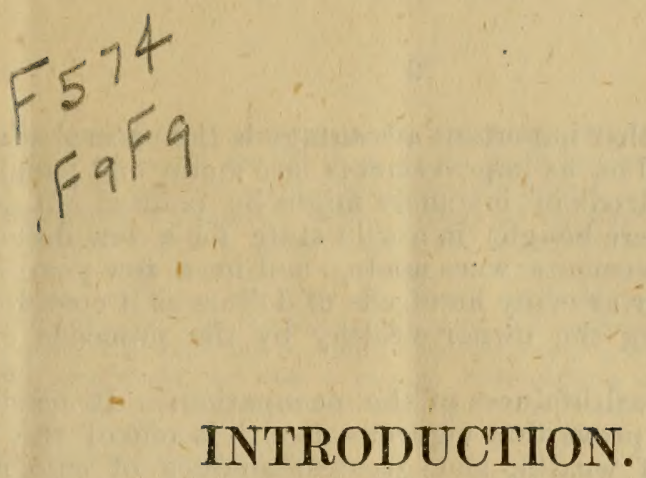

To the men of character, enterprise and intelligence, who are seeking new homes, new fields for business activity, a salubrious climate, beautiful scenery, great natural advantages, and a prosperous society infused with New England principles, and also with the genuine spirit of indomitable energy and advancement, to them the following pages are offered for their most careful and serious consideration.

\section{FRUIT GROWING.}

There are few fields of labor which offer so promising a prospect to honest industry and moderate capital, especially in those sections where the soil and climate are exactly adapted to it, and where marketing facilities are cheap and accessible. Tens of thousands of instances might be shown in which men have engaged with small means and little experience in the growth of peaches, grapes and other fruits, and from several crops have reaped gains which have brought to them a comparative competence. This cannot be wondered at, when the nature of the business is considered, and the peculiar advantages attending it.

First :-It is almost absolutely without any risk or great anxiety. Only a small tract of land is required, so that a small part of a person's capital need to be invested in land-the balance can be judiciously expended for improvements, and the comforts and conveniences of life. The profits of a few acres of fruit will exceed those of one or two hundred acres in a farm. The land is always a safe investment, and its cultivation always profitable. There is no property so secure as the ownership of the soil. It defies fire, floods and thieves. The fluctuations of markets, the rise and fall of goods, and the condition of the stock and money markets, need not cause the fruit grower sleepless nights and terrible presentiments of failure and bankruptcy 
SECOND :-Another important advantage is the natural advance of property in value, as improvements are made and population increases. Hundreds of instances might be pointed out, where orchard lands were bought in a wild state for a few dollars an acre, and improvements were made, and in a few years every acre would sell for as many hundreds of dollars as it cost dollars, meanwhile making the owner wealthy by the proceeds of his fruit.

THIRD:- The healthfulness of the occupation. It needs no demonstration to prove that vigorous health is one of the most precious forms of wealth, and greatest sources of enjoyment. Light and cheerful exercise in the pure open air, constantly aided by the most pleasing influences and impressions, almost insure the continual health of body and mind. And this is not confined to the husband; the wife and children need not be urged to enjoy the fresh air, and partake of healthful exercise; their very surroundings make it almost an impossibility to do otherwise, and as the laws of health are absolute, health and buoyancy of spirit invariably follow. The advantage of a hearty, vigorous family over an invalid, nervous wife and weak, sickly children, no one will dare to estimate by dollars and cents. In the one case life is a burden and disappointment, in the other it is filled with pleasure and satisfaction.

Fourth :-Another advantage is the availability of all kinds of labor. Thousands of families are solely dependent on the labor of the father, and, if deprived of that by sickness or accident, destruction and suffering ensue. There may be several strong, healthy children, but their labor will bring searcely any compensation, and they are a burden instead of an assistance. But in fruit-growing, if necessity requires, the aid of the mother and children may be invaluable, and every boy may become a source of strength and profit to the family. The value of industriots and business habits thus acquired, is more than vast inheritances.

Fifth :-The leisure which is afforded for self improvement. Those who work for others ten or twelve hours a day, year after year, have but little time or disposition for study and reflection. In fruit-growing, much time may be devoted to intellectual pursuits at certain seasons.

When the small capital required, and the safety and healthfulness of this pursuit considered, no business can be found to offer greater attractions. Several hundred dollars profit per acre yearly for well cultivated orchards, vineyards and gardens, is only a usual return. Besides it affords an independent life, which should be prized "above rubies." The following on this subject is taken from an article in the N. Y. Independent of Jan. 21st, 1869 , entitled "What shall we do?"

There are thousands of men in the land to whom the above question is one of the most momentous importance. Thousands of young men just teady to 
leave the parental roof, and commence the battle of life for themselves, look out in the busy world around them to see what business they can engage in that will afford a certain and liberal pecuniary retnrn, a residence in an intelligent and refined community, which confers all the blessings of social, moral, intellectual and religious advancement, and which will yet allow them ample leisure for the improvement of the mind, and the cultivation of those tastes and refinements, which are the glory of a truly civilized people. Thousands of men who have given up the harrassing cares and anxieties of business life, and have retired with a sufficient competence to insure a comfortable support in their declining years, yet wish to engage in something which will relieve the monotony and tedium of mere existence, and which will give to the mind that freshness and exhilaration, and to the body that exercise which are indispensable to the fullest enjoyment of life.

There are thousands of men who have been the sport of misfortune, who are broken down bankrupts and crushed to the earth by defeat and discouragement, who have not the heart or means to enter again into the fluctuating experiences of mercantile life, yet who are compelled to do something to satisfy the necessities of themselves and those dependent on them.

There are also thousands of clerks and book-keepers who have spent the best part of their lives in the harness of servitude; who have but a few hundred dollars to show for their years of toil ; whose pale faces, stooping forms, and debilitated health daily admonish them that they must change their manner of life, or Nature will visit them with a terrible retribution. At the same time the spirit of their manhood is longing for a life-independent, free and unfettered-by which they can sit under their "own vine and fig-tree," and be amenable to no employer but themselves.

There are also thousands of farmers and artizans, once sturdy and full of vigor and endurance, but whose rheumatic pains and over-worked, brokendown frames render them unfit for the exhaustive and incessant toil of the farm, the shop or the factory; whose habits of industry will not tolerate their idleness; but who long for some light, remunerative labor, which would recuperate their enfeebled constitutions and deal lightly with the growing infirmities of years.

There are also tens of thousands of active, enterprising, vigorous, live menwith fertile brains, ready hands, native ingenuity, and indomitable energywho are anxious to engage in some business which opens an illimitable field for all these qualifications, and with genuine pioneer spirit seek a new country and new associations, in which to build magnificent fortunes and raise themselves to positions of influence, dignity and trust.

To all these we offer a few suggestions, which, perhaps, may assist them in finding a satisfactory answer to the momentous inquiry, "What snall we do ?"

It is needless to say that many of the avocations of life are so crowded by earnest competitors, that to engage in them is not only undesirable, but the risk of failure makes it positively dangerous to do so. The professions are thronged by hosts of needy aspirants, who sour their tempers and embitter their lives by their struggles for success, and their almost unavailing efforts to eke out a scanty and precarious existence by all the strategy whlch want and absolute necessity can master.

The road to commercial success iscovered with the unnumbered failures of the vast majority; while only a few exceptions who survive the perilous ordeal, ever reach the coveted reward of a sure and permanent prosperity. In the staid city of Boston, statistics inform us that ninety-five out of every hundred who embark in mercantile life, fail ; and this in spite of the terrific energy, the sharp inventive mind, the industrious and economic habits, and the general morality of the Down East Yankee.

The mechanical trades offer, it is true, a respectable livelihood; but how few, after laboring faithfully the best part of a life-time, have succeeded in giving 
their children a good education, and in raising themselves above the necessity of continual labor!

The farmer, independent as he is, has generally to toil early and late for nearly a life-time, before he surrounds himself with the conveniences of life; and he enjoys a comparative competence in his old age, if at all, at the fearful sacrifice of a body rendered prematurely infirm and miserable.

There is one branch of industry against which the foregoing objections cannot be urged. It is comparatively undeveloped, and in certain localities the extent of its boundless wealth and resources are not even suspected. We refer to our fruit interests, and especially that of the peach. The localities for the successful culture of the peach are yearly becoming fewer and more contracted ; and, hence, in those favored spots which seem especially designed by Providence for that purpose, any labor expended is sure to be repaid with a munificent reward. The peach is one of the most delicinus fruits of any clime, and the demand for it is absolutely unlimited. In the Western States it can only be grown with certainty and success in the celebrated "Michigan Peach Belt"a strip of land perhaps fifteen miles wide, on the eastern coast of Lake Michigan, which seems by the peculiar modifications of the lake on the climate, together with a soil of wonderful adaptation to the culture of all fruits, to combine every requisite which the most fastidious horticulturist could suggest. The great Northwest, and many sections of the Middle and Eastern states, are mainly dependent on this tract for their supply of this luscious fruit; and when we think of the mighty cities, populous towns, thrifty villages, and immense rural districts, filled with homes of wealth, luxury and refinement, in this the most wealthy and populous portion of the continent, it is utterly impossible for the mind to estimate or conceive the consumption of such a people and the demands of such a market. But nature would seem determined to keep pace in her profuseness to man, with his wants. The extraordinary success with which the peach producer has been already rewarded must soon cover such portions of this tract as are convenient to ports and rail-roads; so as to afford market facilities, with flourishing orchards, which shall supply our markets and tables.

In the fruit business, much depends on the accessibility of a ready market; and when this is combined with the foregoing advantages of climate and soil, that is the location to be chosen above all others.

The attention of the reader is now ealled to a portion of the "Michigan Peach Belt" referred to, which, it is claimed, offers greater inducements to settlers than any other point, and they are invited to a serious consideration, and thorough investigation of the facts. The two most desirable localities for peaches and other fruits, are the Grand Haven and St. Joseph regions. The vicinity of Grand Haven is considered by far the most preferable for the following reasons:

1st.-The climate is better adapted to peaches, owing to the prevailing S.W. winds sweeping over 100 miles of open water, and consequently the crop is more certain.

2nd.-Thelands are near a good harbor and rail-roads, neither of which St. Joseph has, thus commanding the eastern as well as the Chicago, Milwaukee and all the lake markets.

3d.-Lands with treble the natural advantages, can be obtain. ed at one third the price.

These facts will be noticed particnlarly hereafter. 


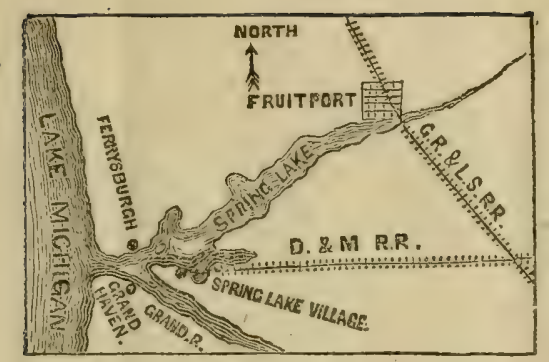

Grand. Haven is a eity of about 5,000 inhabitants, is one of the most important places, and has the best harbor on the eastern shore of Lake Michigan. It is the western terminus of the Detroit \& Milwaukee rail-road, which connects here with a line of steamers to Milwaukee. There are two lines of propellers to Chicago, by which two boats leave for Chicago every evening during navigation, and arrive there next morning. There are also two boats daily, during navigation to Grand Rapids, running on Grand river. Visitors will find immediately at Grand Haven, barren sand-banks, such as exist all along the eastern shore, but back two or three miles the soil becomes loamy, and the country beautiful.

Abont a mile from Grand Haven on the North side of Grand xiver, is the village of Ferrysburgh. On the opposite side of the river, or ratleer of the chaunel which constitutes the outlet of a beantiful little lake, ealled Spring lake, lies the village of Spring Lake with 1,500 inhabitants. At these villages are some of the largest manufacturing establishments in the country, and surrounding them are orchards and gardens of the finest description. Spring Lake, just alluded to, is a lovely sheet of water, stretching inland, about five miles in length, and from one-half to ore mile in width. Along its banks are numerous streams of pure cold water. The banks rise precipitously from the water, from thirty to sixty feet, and nearly anywhere a vessel can run so near the shore as to load up from the beach. The lake is of ample depth for the largest lake propellers and vessels to navigate," averaging about fifty feet in depth. On its banks are extensive beds of pure, fine, fawn-colored clay, excellently adapted for bricks and pottery. There are also deposits of valuable white marl in the vicinity. The elevated shores are being rapidly covered by handsome residences and thrifty orchards, vineyards and gardens. At the head of the lake, and commanding a magnificent view of nearly its whole length, as it stretches aw ay like a thread of silver, is laid out a charming town-site called Fruitport, and this must soon become the centre of one of the most prosperous firuit-growing communities in the country. It is laid out with unusaal liberality. The streets are of more thin ordinary width, and ample appropriations are made for public-squares, school-grounds, fine public park, \&c.

An extract is here given from a private letter written by $\mathrm{F}$. J. Hough, Esq., of Adrian-a gentleman who is thoroughly familiar 
with all Western Michigan, and one of the most influential and reliable business men of the State. He writes as follows:

- My attention was first directed to the advantages which Spring Lake hac? over other points on the lake shore, in the Spring of 1867 . I had often been at Grand Haven and had, in view of the sand hills which surrounded it, formed a very unfarorable opinion of all of the surromuling country. I knew it had the be st harbor on the const, but was not aware that there was such a magnificent inland lake [Spring Lake] connected with its harbor, with a fruit and farm country surrounding, and in its vicinity, unequalled by any section of Michigan. A friend who had visited the head of Spring Lake, first called my attention to its great natural advantages, and from his representations I became so interested as to visit it, and must acknowledge that, having traversed the lake shore from Michigan City to Hanistee, I know of no locality that presents so many advantages to the fruit-grower and agriculturalist, as Spring Lake. I have often wondered why a point possessing so many advantages to the settler, should be so long overlooked. I can account for it in no other way than thisthe attention of business men has been given only to the lumbering interests, while travellers like myself, passing along the line of the Detroit \& IIilwaukee rail-road, or through the swamps from Ferrysburgh to Nuskegon, would judge of the whole country by the portion seen along those roates. The facilities for marketing fruit or produce at Spring Lake, are far the best of any point on the shore-while the certainty of growing a crop is equally as good as the best, and much better than some of the localities further south. I have several times visited the localities of St. Joseph, South Haven, Pier Cove, Saugatuck and Holland, and have made inguiries as to the price of land, and this is the result of such inquiries: I find land at Spring Lake, with double or treble the advantages of reaching the markets of Chicago, Milwaukee and those of the East, cars be bought from one-half to one-third less per acre. This state of things cannot long exist. The beautiful scenery, healthful climate, good society and fine fruit lands of this section are beginning to attract attention, and a tide of emigration is destined to set in towards this portion of our state, as will make it, as its natural advantages entitle it to be, the richest fruit-growing section of the West."

Such are the statements of a prominent business man, and he has no connection whatever with the "Fruitport. Orchard \& Vineyard Company."

Several gentlemen having their attention called to the extraordinary natural advantages of this locality, and believing that by judicious management, and a liberal and publirespirited policy, a wealthy, populous and intelligent community could soon be founded, secured a large tract of the choicest fruit lands, and organized the "Fruitport Orchard \& Vineyard Company," for the purpose of uniting their interests and labor, to facilitate their business, and better enable them by combined and harmonious eftorts, to develop the marvelous resources of the country by every available means. It is their aim and purpose to build up ar intelligent and refined community of actual and permanent settlers, who will appreciate and cherish a high-toned, moral public sentiment, and those invaluable religious and edncational interests, which make the solid basis of a permanent prosperity. To such, extraordinary inducements are offered, which, it is believed, no other locality presents.

This Company are making preparations to build a dam at the 
mouth of Norris Creek, emptying at the head of Spring Lake, obtaining about eighteen feet head of water, and preparatory to the erection of grist and saw mills and various manufactories. This they intend to prosecute with vigor, until completed. This will flow the water back on narrow bottom lands about three miles, thus forming a large artificial lake, navigable for barges, which will afford a ready outlet for fruit, produce, rail road ties, lumber, wood, \&c., from the lands adjoining, to the vessels at the Fruitport docks. The Grand Rapids and Lake Shore railroad, which is progressing with the utmost rapidity, will run directly through Fruitport.

It must be seen that these rail-road facilities, together with one of the finest harbors of any country, must make Fruitport an important business place. As soon as the rail-road is completed, boats can make connections with trains, and Fruitport can compete with Grand Haven in the freight and passenger business, to Chicago and other lake cities. The position of Fruitport speaks for itself, and needs no further comment.

Information is now given on the leading features of the country, and on topics of the greatest importance to those seeking a new home. The liberty has been taken to make extracts from a very able paper and report by Prof. Winchell, late State Geologist of Michigan, and now Prof. of Geology in Michigan University.

\section{CLIMATE.}

Prof. Winchell in a paper on the "Fruit Belt of Michigan," says : "Lake Michigan being a body of water 350 miles long, and on an average, 75 miles broad, with a depth of about 900 feet, is enabled to preserve something of that uniformity of temperature, which characterizes the ocean, and exerts a similar influence upon the contigious lands. The temperature of the water never rises above $45^{\circ}$ or $50^{\circ}$, and probably does not sink below $35^{\circ}$ or $40^{\circ}$. The great body of the lake is never frozen over. The winds moving over its surface are consequently warmed in cold weather, and cooled in warm weather. As the prevailing direction of the wind, both summer and winter, is from the westerly points of the compass, the influence of the lake is most extensively felt along the Eastern or Michigan shore. The amount of this influence diminishes toward the interior, but is distinctly felt in extreme weather, in all parts of the State. The region of country along the lake, however, for a distance inland which may be about 40 miles, enjoys a climate of a decidedly local character. 1) uring the prevalence of the severest cold of last winter, (1867) the mereary stood from $15^{\circ}$ to $20^{\circ}$ lower at Milwaukee than at Grand Haven, immediately opposite. A region defended, like that along the eastern shore of Lake Michigan, from the extreme vicissitudes of our Northern winters, and preserved equally from 
the torrid heats and protracted drouths of our Southern summers, would seem to be favorably situated, for drawing forth the utmost capacities of the soil. As it is obvious that a favorable soil is an essential condition to the full effect of so propitious a climate, I ought to add, that on the immediate shore of the lake, the soil is generally sandy, and covered by a forest growth, consisting of evergreen and deciduous trees, intermixed. From half a mile to three miles inland, the soil becomes more loamy." Prof. Winchell says elsewhere, "Our cold winds generally proceed from the Southwest or TVest. Passing over the open water of Lake Michigan, sixty miles in width, the temperature of which never sinks below $32^{\circ}$, it is impossible to avoid abstracting a considerable amount of heat, so that when these cold westerly winds strike the Michigan shores of the lake, the severity of the winter gales is materially mitigated. The equalizing influence of the lake is much greater than is generally supposed, and the whole belt of comntry bordering it on the East, is affected by its hydrographical position, much like the peninsula of Florida, Sweden and the British Islands." He claims that the Northwestern shore of Michigan is far better protected than the St. Joseph region, for the very obvious reason that the Southwest winds sweep round the head of the lake, or pass over a small borly of water, before striking the latter place, but cannot tonch the Northern shore, without passing over the entire width of the lake, which, as before said, greatly mitigates their severity. He says of the Northern shore, that "the tubers of the dahlias remain in the earth with impunity, and delicate green-house roses stand ont with greater security than in Alabama and Louisiana." As to its fruitgrowing capacity, he says "I doubt whether any other portion of the United States, east of the Rocky Mountains, will be able to compete with it. It has been a complete surprise to the inhabitants to learn that peaches, apples, grapes, pears, raspberries, strawberries and other fruits, can be cultivated with success. The discovery has given a wonderful impetus to this branch of enterprise; and unless my judgment greatly misleads me, we shall hear of this region as the fruit orchard of the conntry, and shrewd men with horticultural tastes, will thank me for direeting attention to this open avenue to wealth." Such are the statements of one of the ablest scientific authorities of the United States, who is thoroughly familiar with the region, and surely no one is better qualified to give a correct and reliable opinion on this subject.

\section{FRUITS.}

At a convention of Fruit Growers held at Spring Lake, Feb. 3,1869 , the extraordinary fact was rouched for by practical fruit growers, that at Spring Lake and vicinity, during the last ten years, there had only been one total failure of the peach crop, 
and only two partial failures, while at St. Joseph there had been only four full crops of peaches during the same time. The writer of this was shown a fine old orchard at Spring Lake, by a gentleman residing near it, who said it had borne every year for the lnst eleven years, to his personal knowledge, and was an old bearing orchard when he first saw it, and this, too, without particular care. There is a peach orchard more than two miles inland east of Fruitport, which has yielded a full crop every year for the last twelve years, and others less distant are equally prolific. For the reasons already given, this region is better protected from winter winds, consequently the peach crop is far more certain. The profits from some orchards seem almost incredible to believe. Last year the profits of some orchards were about $\$ 1000$ per acre. There were exhibited at the convention alluded to, some of the most superb apples ever seen, which grew in the vicinity, and all the facts cited on apple raising, showed that trees bear at an early age, and with a prolificacy that is truly astonishing. The experience given as to the yield and profits of grapes and small truits, was also remarkable. A nurseryman and fruit grower (Mr. Ganzhorn) of several years experience at Spring Lake, said that the strawberry, raspberry and blackberry, conld be successfully cultivated at a profit of fiom $\$ 500$ to $\$ 1,500$ per acre. The above is taken from the Report of the Convention, and also the following item : "Mr. Jno. L. Edgar's expericnce with strawberry culture had been a success. His first crop from about 75 rods of ground had yielded 117 bushels of berries, which he sold for $\$ 555$. Eighty bushels, sold in Milwaukee, brought him $\$ 9$ per bushel. For the 'Jucunda' he received 30 cents a quart." These facts speak for themselves, and need no further comment. They show that Prof. Winchell's opinion is no exaggeration when he " doubts whether any other portion of the United States, east of the Rocky Mountains, will be able to compete with this country as a fruit-growing region." But the best evidences are the orchards, vineyards and gardens themselves, and to show the extent and progress of fruit-culture in the vicinity of Grand Haven, the following is taken from the paper of Prof. Winchell, before referred to: "From the statisties of the "Lake Shore Horticultural Association,' I learn that there are already under cultivation, in the imnediate vicinity of Grand Haven, 7,603 apple trees; 1,286 pear trees; $26 ; 580$ peach trees; of which 12,664 were set last Spring. Of plum, nectarine, apricot and quince trees, there are 756. There are 18,693 grape vines, of which 1,700 are bearing, and 14,993 newly set. These trees, and many others which I have recently examined, are in a state of health and vigor which cannot be surpassed." He then says that still further North "it seems to be completely demonstrated that these fruits are destined to be as successfully cultivated as in the St. Joseph region." Since 
then fruit-growing has received a wonderful impetus, and there are now several times that number of trees and vines uncler cultivation.

\section{SOII AND TIMBER.}

The soil at Fruitport and vicinity, is a rich, warm, sandy loam, exactly adapted to fruit-growing. It is far richer and heavier than the soil at Spring Lake and near the Lake Michigan shore. Prof. Winchell's statement of this fact has been eited before. Every acre offered for sale by the "Fruitport Orchard and Vineyard Company" is dry, elevated and undulating, without hills, rocks, stones, or a foot of waste land. Until fruit trees and vines bear, immense crops of potatoes can be produced, so that the land pays from the very first year. Some tracts are covered by a heavy growth of valuable timber, principally hemlock, maple, beech, white ash and cherry. The timber is magnificent--many noble monarchs of the forest, of immense proportions, run up, like a mast, 50 or 60 feet, without a branch. There are single trees on nearly every acre, which will more than pay for the acre, at the prices at which these lands are now offered. The beech can be cut into cordwood for $\$ 1.00$ per cord, and will sell for about $\$ 3.50$ per cord at the vessel. Hemlock tan bark can be cut for $\$ 1.50$ per cord, and sells from $\$ 5.00$ to $\$ 8.00$ per cord. 'The logs can then be sold, or sawed in lumber. The white ash and cherry can be sawed and shipped to Chicago, where it is worth from $\$ 25$ to $\$ 40$ per 1000 . There are a great many small hemlock trees which run up straight, from 30 to 50 feet, and which will make from three to five railroad ties each. The price for cutting ties is eight cents each, and they sell at the creek for about 25 cents each, and at Chicago for about 40 cents. The ties alone, will pay for the land on many tracts. These prices will be much enhanced as shipping facilities are increased, and the rates of freight become more reasonable, but above all, by the fact that every year the consumption of all these articles increases enormously, while the supply is rapidly diminishing. A Chicago hardwood lumber merchant recently informed the writer that there was far more difficulty in obtaining hardwood lumber than in selling it. Ash, cherry and maple are constantly applied to new uses, and are rapidly increasing in value. The labor of preparing the land for cultivation is not very great, for there is no underbrush and no grubbing or digging up of saplings. The custom is, to plow with the stumps in, and to set out the fruit trees or vines, and plant potatoes, without attempting to take out the stumps. They are not so close together but that the ground can be well cultivated, and they soon decay so that they can be removed. The ground pays a large profit from the beginning, by crops of potatoes and regetables. Peach trees bear to some extent the third year after planting, but there is not a full crop till the fourth year. At Fruitport one of "Hales 
Early" nursery trees produced ten full grown luscious peaches fourteen months from the setting. The timber is of great value to the settler, for in the winter months he can cut wood, railroad ties and $\operatorname{logs}$, and sell them for cash, and thus make high wages, besides large profits. Experienced men have made estimates of the timber on some tracts, and consider the following figures safe, and underneath the actual amounts. On an acre there are:

50 railroad ties, worth say 22 cents each........\$11.00

6,000 feet hemlock lumber " $\$ 8.00$ per $1000 \ldots \ldots \ldots 48.00$

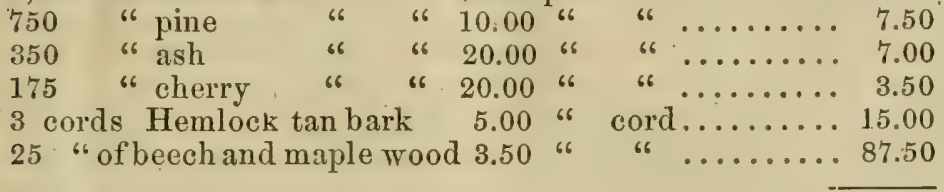

$\$ 179.50$

It will be seen that the above are minimum prices. When all this is taken off the land, it will sell for far mure than it cost, because fruit-growing is so profitable, that cleared land cannot be obtained fast enough. Suppose we allow one-half for cost of cutting, handling, \&c., even then an acre elears \$89.75 in cash, besides a large amount of small wood for fuel, and the land is cleared ready for fruit purposes. Some of these lands are offered for less than half of the net profits on the timber alone. Thus it will be seen that a man can make high wages while he is cutting his timber, obtains his fine fruit land for nothing, and receives a handsome sum of money per acre besides. If every State in the Union were challenged, could a locality be pointed out, offering equal inducements or so generous a reward? The facts and figures given above are a sufficient answer.

\section{HARBOR AMD MARKETS.}

The splendid natural harbor of Fruitport, has already been deseribed, and its importance to these lands will at once be seen. Every one knows that freights by water, are vastly cheaper than by rail, so that the fruit, produce, lumber, \&c., can all be shipped at low rates, and the competition of vessel and propellor owners will have the tendency to reduce their prices in the future. This water communication brings these lands, practically for marketing purposes, in close proximity to Chicago and Milwankee, so that a ready and accessible market is always certain. There is not another point on the eastern shore of Lake Michigan, with so good a harbor, and possessing such varied resources and extraordinary natural advantages. Butbeside the harbor, there are the railroads, which make the Eastern market accessible, and which make sure grow th and prosperity doubly sure. These two pow erful interests 
combined, will very soon bring to it that business life and activity, and that commercial importance which its position and resources indicate.

\section{MANUFACTURING AND BUSINESS.}

The shipping facilities of Fruitport, together with the immense quantities of the finest ash, maple, cherry, hemlock, beech and pine, which are tributary to it, are such that for many kinds of manntacturing, it camnot be surpassed. The expense of wood for steam power is scarcely more than the cutting, and there will be fine water power when the dam is completed. For the manufacture of loricks and pottery, it is affirmed that it cannot be equalled in the West. There are immense beds of the purest fawn-colored clay on the banks of Spring Lake, which are covered by a layer of saud, and these make bricks, which Chicago architects, builders, and brickmakers, all admit, are of a hardness, fineness of textmre, smoothness of surfice, and of a beautiful, white marble-like color, which is superior to any bricks ever seen by them before. There is one yard already in operation with a capacity of from 20,000 to 30 ,000 per day made with a machine driven by steam, which cost about $\$ 5,000$, complete. These bricks will readily bring in Chicago, from $\$ 15$ to $\$ 20$ per 1000 , and can be shipped cheaply by water. So tar, the bricks have been sold at the yard at $\$ 12$ per 1000 . Vessels can rtun up to the yard and load up. As for the manufacture of pottery, those familiar with the profits of the business, can readily appreciate the advantages already noticed. A point, destined as this is, very soon, to be a populous and prosperous community, and possessing so many extraordinary resources of wealth, affords a tine field for all branches of business.

\section{HEALTH.}

The climate of this region is more even and salubrious than that of any other inland State. The prevailing breezes are from the Southwest, and come laden with all the elasticity and invigorating properties which Lake Michigan can inspire. Prof. Winchell says, in speaking of Northern Michigan: "Billious diseases are foreign to the country. No ague was ever known to be indigenous to the region. The uniformity of the temperature, and the purity of the air and water, are also fivorable in pulmonary diseases, and I have learned of some rheumatic affections that had been cured by a few month's residence." The lake breeze sweeping up the length of Spring Lake, together with the beautiful scenery, makes Fruitport one of the most healthful and attractive locations for residences that can be found. As a summer resort for health and recreation, it has few equals, and doubtless its charms will attract many who are in search of homes, with beautiful surroundings: and in a healthful, bracing and uniform climate. 


\section{ADVANCE OF PROPERTY.}

Any one familiar with the history and growth of the West, is well aware that the rise of property based on the healthy growth and development of a town or community, is one of the surest and easiest sources of profits, and has alone brought independence to thousands. Careful examination and deliberate judgment, will enable a person to perceive the natural advantages of a location, and the tendency of events and improvements, which must make it an important point, and thus sagacious men are careful to locate where they will participate in the wonderful growth and prosperity which is sure to follow such signs.

Fruitport and vicinity, is not surpassed, in indications of future prosperity. At St. Joseph, wild lands sell from \$100 to $\$ 500$, and orchards from $\$ 300$ to $\$ 1200$ an acre, according to location and improvements, and this without a railroad, and with a poor harbor, which renders navigation dangerous, and in rough weather impossible. At Fruitport, with a splendid harbor, a railroad soon to be completed, more certainty of crops, and treble the natural advantages, choice lands can be obtiined for onethird of St. Joseph prices. 'This can not long be the case. These lands now offered from $\$ 25$ to $\$ 50$ per acre, will soon be worth at least as much as St. Joseph lands.

\section{THE CHARACTER OF THE PEOPLE.}

Most of the people at Fruitport and vicinity, are from the East, hut Western pluck and go-aheaditiveness has also many excellent representatives. They are thoroughly imbued with the great icleas of the age, and the institutions of education and religion are supported and appreciated with genuine Eastern zeal. It is the priule and ambition of the originators of this movement, to found a community, wliose refinement, virtue and intelligence shall be as remarkable as their material prosperity, and they are directing their efforts accordingly. By the course they are pursuing, and will pursue in the future, they will succeed in bringing together, what they most earnessly desire-the most select people, and thus secure those invaluable blessings which refined and cultivated society alone can confer. The sale of intoxicating beverages are expressly forbidden, and their exclusion becomes a part of the contract of every deed.

\section{PRICES.}

Town lots in Fruitport, of 1 acre each, commanding a magnificent view of the harbor, from $\$ 150$ to $\$ 200$, and a limited number to those who will build the present season, \$100 each. Choice parcels near Fruitport of 5 acres each, for orchards and vineyards, from $\$ 150$ to $\$ 250$ each, and ten-acre lots from $\$ 250$ to 
$\$ 400$. Some tracts of fine fruit land, covered by heavy timber, are offered from $\$ 20$ to $\$ 30$ per acre, according to distance from the town. These are cash prices, and are-fully one-third lower than in any peach-growing location on the eastern shore of Lake Michigan, while the advantages are vastly superior, as has been shown. The Company deem it the best policy, to offer extraordinary inducements, and sell a portion of their lands at extremely low rates to actual settlers and residents, and thus enhance the value of the balance. The title is indisputable, and full warrantee deeds will be given.

\section{A GOOD HOME}

can be secured for a small amount of money. A few acres of fine fruit land at the prices given, is within the reach of nearly every one. Building material is cheap-timber plenty, and mills convenient, so that improvements can bo made at small expense.

\section{ROUTES.}

If in the East, proceed to Detroit, there take the Detroit \& Milwauke Railroad to Spring Lake; when there, inquire for the Middlemist House, and directions will be given as to going up Spring Lake to Fruitport. If in the West, proceed to Chicago, and take the propellor for Grand Haven, at Goodrich's dock, and from Grand Haven to Spring Lake, \&c.

\section{CLOSING REMARKS.}

Information has been given as to the general subjects of inquiry connected with Fruitport, and it is nothing more than a simple statement of facts. If the statements seem to be extraordinary, it must be remembered that this is an extraordinary region, and an accurate description must, to some extent, appear the same. It is believed that what has been said, will be abundantly corroberated by every intelligent person, after a careful examination of this locality. Visitors must expect to see a new place; but they will find the splendid natural advantages, and the plain indications of speedy growth and prosperity, which have been enumerated. The great leading facts given herein, were not asserted by the Company or any one connected with it, but by one of the highest scientific authorities in the United States, recently State Geologist of Michigan, and now Professor of 
Geology in Michigan University-positions which, above all others, qualify him to speak as he has done. The statements of one of the most highly respected, and leading business men of the State are also given, and both these gentlemen made these assertions before the "Fruitport Orchard \& Vineyard Company" was ever dreamed of, and it has therefore been deemed preferable to make use of their statements.

The foregoing probably gives all the information which parties may wish before visiting Fruitport, but if further particulars are desired, address as briefly as possible,

E. L. CRAW, Fruitport, via Spring Lake, Michigan. 


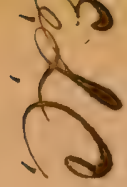

LIBRARY OF CONGRESS
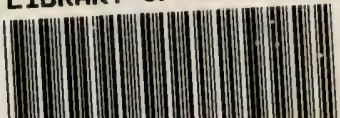

00160994770 


